\title{
Honouring Inuit women's educational and employment experiences through Indigenous storywork methodology
}

\author{
Tina Wasilik \\ Department of Secundary Education, University of Alberta
}

\begin{abstract}
The legacy of the Arctic Residential School system is still present in Nunavut education today. Inuit in Nunavut continue to receive a westernized education that does not fully encompass traditional Inuit learning principles. However, a group of Inuit women, enrolled in a Northern College Early Childhood Education (ECE) Diploma Program from 2015-2017, uniquely blended a child-centred educational approach with traditional Inuit learning methods. Through the Inuit women's practicum placements completed at a preschool, they developed selfconfidence and a skill set that led to their employment and self-reliance.

The Oxford dictionary defines self-reliance as "the ability to do or decide things by yourself, rather than depending on other people for help" (Oxford University Press 2021). This definition does not fully capture the essence of selfreliance from Inuit women's perspectives. Their self-reliance is greatly tied to a combination of domestic work, wage work, and land-related work that forms a unique framework to capture the specificity of northern women's self-reliance. My research study will explore the personal experiences of these Inuit women graduates. The study intends to inform institutional decision-making, determine how to best support the Inuit women's educational access and success, contribute to the scholarly work in the field of education and advance future Inuit training and employment initiatives.

My research questions are: What does self-reliance look like from an Inuit woman's point of view? How did participating in the 2015-2017 ECE Diploma Program influence the Inuit women's lives?

Indigenous Storywork is grounded in Indigenous Research Framework (Lavallée 2009) which allows for connections between people, their ancestors, and the natural world. Indigenous Storywork guides my study theoretically and methodologically. I will use Storywork to engage in holistic meaning-making that involves the heart (emotions), mind (intellect), body (physical actions), and spirit (spirituality) (Archibald et al. 2019).

Storywork is essentially a three-part framework: story-making, storytelling, and connecting with specific cultures and peoples experiences through stories (Archibald et al. 2019). This framework honours distinctive traditional Inuit knowledge and these Inuit women's holistic identity regarding their relationships with themselves, family, community, land, environment, and the wider society. Indigenous Storywork methodology creates space for my participants to share dreams, visions, spiritual encounters, and lived experience stories through interviews. My research honours the Storywork of Inuit women through their culturally responsive and unique educational opportunities.
\end{abstract}

Keywords: Indigenous Storywork, Inuit women, early childhood education, Inuit training and employment, Nunavut

\section{References:}

Archibald JA., Lee-Morgan J., \& De Santolo J. 2019. Decolonizing research: Indigenous storywork as methodology. London (UK): Zed Books Ltd. Lavallée, L. 2009. Practical application of an Indigenous research framework and two qualitative Indigenous research methods: Sharing circles and Anishnaabe symbol-based reflection. [accessed 2021 Jun 3]; 8(1): 21-40. The International Journal of Qualitative Methods. doi:10.1177/160940690900800103. Oxford University Press. Self-reliance. Oxford Leaner's Dictionary; [accessed 2021 June 3]. https:// www.oxfordlearnersdictionaries.com/definition/english/self-reliance

Cite as: Wasilik T. 2021. Honouring Inuit women's educational and employment experiences through Indigenous storywork methodology. Alberta Academic Review, Vol 4 (1): 11, EEGSA-SEGSA Special Issue: Remote Connections, DOI: 10.29173/aar118 